\title{
Wasteland Utilization for B. balcooa Cultivation: Socio-economic and Environmental Impacts through Bamboo-based Product Development
}

\author{
Beena Patel ${ }^{1 *}$, Bharat Gami ${ }^{2}$, Akash Patel ${ }^{1}$, Pankaj Patel ${ }^{1}$ \\ 1 Abellon CleanEnergy Ltd., Research and Development Department, Bodakdev, Ahmedabad, INDIA \\ 2 Abellon Agrisciences Ltd., Bodakdev, Ahmedabad, INDIA
}

*Corresponding Author: beena.patel@abelloncleanenergy.com

Citation: Patel B, Gami B, Patel A, Patel P (2019). Wasteland Utilization for B. balcooa Cultivation: Socioeconomic and Environmental Impacts through Bamboo-based Product Development. European Journal of Sustainable Development Research, 3(4), em0103. https://doi.org/10.29333/ejosdr/5957

Published: October 11, 2019

\begin{abstract}
Declining fossil fuel and increasing $\mathrm{CO}_{2}$ emissions from non-renewable fuel leading us to climate change which signifies to reduce fossil fuel dependency and promotes bioenergy as renewable. To address such issue Abellon Clean Energy has developed captive farming of B. balcooa for environment friendly bio-energy feedstock cultivation in; 1112, 2223, 2964 and 6175 plants/hectare densities to understand cost of cultivation and its subsequent use in cottage industry, energy substitute and high value products. Farmers' field trials were also performed as 1112 plants/hectare at three districts of Gujarat. The optimum plantation density was observed to be 1112 plants/hectare at captive and farmers' field having approximately 57.70 MT/hectare biomass yield with 32-39 USD/MT cost of production. If 5\% of waste land of India cultivates B. balcooa, with $50 \%$ biomass yield, 67.51 million metric tonne $(\mathrm{mMT}) /$ year bamboo biomass can be produced. Bamboos generates worth of 9788 million USD or 7696 million USD yearly from handicraft and construction respectively. Bamboo grown at marginal ecologies can fetch around $12.83 \mathrm{mMT} / \mathrm{year}$ from cottage industrial products worth of 16616 million USD reducing bamboo import. Waste from cottage industries can produce annually bio-energy pellets worth of 13987 million USD which could replace 63.18 mMT of coal or $21.60 \mathrm{mMT}$ of LPG. Optionally 7560 million liters/year of bioethanol can be produced out of waste generated from incense stick processing worth 5670 million USD. Further 30\% of bamboo from marginal land cultivation can produce $20.25 \mathrm{mMT}$ /year of activated charcoal worth of 34425 million USD. Indirect employment of 8.66 million people is accounted for incense stick, pellet production, logistics, marketing, etc. B. balcooa has potential for carbon sequestration through marginal land development impacting India's social, economic and environment conditions that also improves soil quality.
\end{abstract}

Keywords: Bambusa balcooa, bamboo, bioenergy, biofuel, $\mathrm{CO}_{2}$ sequestration

\section{INTRODUCTION}

Fossil energy use has skyrocketed dramatically over the last two centuries due to globalization and industrialization. These lead to exhaustion of fossil fuel in societies causing energy crisis. Scientists have raised their voice to warn about climate change, caused by the burning of fossil fuel and extraction of fossil fuels in order to produce energy. Renewable sources of energy have gained focus from global leaders and policy makers to reduce fossil fuel (World Energy Council, 2014). Biomass is been focused due to its a promising potential as renewable energy having hydrocarbon source and its downstream use for renewable heat and renewable power generation (A. Patel et al., 2017). Harvesting of various crops in India produces large volume of residues both on and off farm. Ministry of New and Renewable Energy reported generation of around $500 \mathrm{Mt}$ of crop residues annually. 
Farmers burn these crop residue (Bhuvaneshwari, Hettiarachchi, and Meegoda, 2019; Ministry of Agriculture, 2014). An alternative to crop residue is to grow short-rotation woody crops and grasses as dedicated energy crops.

Bamboo being grass family can be cultivated as fast-growing species and can be converted through thermal or biochemical process to different energy products such as energy pellets, activated charcoal and bioethanol which could replace fossil fuels (Truong and Anh Le, 2014). However, a secure and stable supply is to be ensured through additional information on the availability, cultivation, and harvesting operations of bamboo that gives feasibility for sustainable use of bamboo. Thousands of hectares of degraded farmers' fields have been transformed by bamboo plantation in Allahabad city of India. Value chains for bamboo to support landscape restoration and prevent land degradation is also been discussed by INBAR to meet demand sustainably. This will also act towards resilience to climate change (Kate, 2014).

Bamboo serves ecosystems including soil improvement, pollutants filtrations in runoff, reduce soil water and wind erosion, reduce net emissions of greenhouse gases, fix soil organic carbon and improve habitat diversity (Gu et al., 2019; B. Patel, Gami, and Patel 2017; Tardio et al., 2016; Yourmila and Bhardwaj, 2017). The challenge is to establish bamboo plantations on a large enough scale to provide a constant and sustainable supply of biomass. National Bamboo Mission (NBM) of India and NABARD (NABARD, 2018) suggested waste land development through bamboo plantation as bio-energy crop along with value stream product development for socio-economic and environmental benefits. However, it is essential to demonstrate bamboo cultivation and its downstream application on marginal ecologies at a scale to strengthen its viability to growers and policy makers. To achieve that the objective of this study is to (1) cultivate bamboo at marginal waste land and farmer's field to understand yield based economy; (2) its subsequently value chain proposition as bioenergy feedstock to be used as bio-pellets, biofuel ethanol, charcoal and handicraft products and incense stick and (3) socio economic and environmental impact across bamboo supply chain from cultivation to values chain products.

\section{MATERIAL AND METHODS}

\section{Bamboo Captive Farming and Farmers' Field Trials}

Marginal ecologies for cultivation of bamboo were selected on the basis of soil sample characteristics. To evaluate the biomass yield of bamboo on regional marginal land, Gujarat state was selected for large scale bamboo cultivation study. Bamboo plants (B. balcooa) were captively cultivated at Rameshwar Kampa, Modasa, and Aravali district at $23^{\circ} 33^{\prime} 35.19^{\prime \prime} \mathrm{N}$ (latitude), $73^{\circ} 17^{\prime} 7.95^{\prime \prime} \mathrm{E}$ (longitude) at four different plant densities (1112 plants/ha, 2223 plants/ha, 2964 plants/ha and 6175 plants/ha) to evaluate the effect of plant density on the yield of bamboo. The soil of experimental sites is porous, rocky and having lower water retention capacity which falls under marginal ecology category. The mean temperature between minimum and maximum at this captive farming site during summer is $29^{\circ} \mathrm{C}$ and in winter, it remains $25^{\circ} \mathrm{C}$. An average relative humidity ranges from $26 \%$ in March to $75 \%$ in July. The site gets rainfall during June to September in every year with average rainfall ranges from $105 \mathrm{~mm}$ to $310 \mathrm{~mm}$.

Standard agronomic practices recommended by National Bamboo Mission (BTSG-KFRI, 2015) were followed for bamboo cultivation and maintenance. Effect of bamboo plantation on soil of marginal ecologies was also assessed by pre- and post-cultivation soil analysis.

Bamboo plants were also cultivated at farmers' fields at three different locations in Gujarat i.e. Laxmipura (Aravali District) at $24^{\circ} 0{ }^{\prime} 32.88^{\prime \prime} \mathrm{N}$ (latitude), $73^{\circ}$ 6' 10.93" E (longitude), Vadod (Surendranagar District) at $22^{\circ}$ $33^{\prime} 33.3^{\prime \prime} \mathrm{N}$ (latitude), $71^{\circ} 38^{\prime} 56.2^{\prime \prime} \mathrm{E}$ (longitude) and Aakru (Bhavnagar District) at $22^{\circ} 16^{\prime} 05.5^{\prime \prime} \mathrm{N}$ (latitude), $71^{\circ}$ $59^{\prime} 35.5^{\prime}$ " E (longitude) with 1112 plants/ha plantation density to study the growth of bamboo under different field conditions.

Growth of bamboo plants cultivated at captive farming site and farmers' fields were regularly monitored and plant growth data were recorded. Total 100 bamboo clumps were harvested to calculate per ha bamboo yield after the third year of plantation. Overall clump yields and total culm dry weight were recorded.

\section{Calculation of Bamboo Production Cost}

Bamboo production cost for all densities in captive farming as well as farmers' field trials have been calculated based on farm inputs like cost of land preparation, irrigation, labour cost, fertilizers and equipment costs for cultivation as well as harvesting of biomass. Cost data were recorded in form of USD per ha and USD per MT biomass production.

\section{B. balcooa Cultivation at Marginal Wastelands}

Marginal wasteland area for India was calculated based on data published in wasteland atlas of India. From total wasteland available in India, 5\% wasteland was considered to be cultivated for bamboo production. Bamboo 
biomass yield for B. balcooa on marginal wasteland was assumed $50 \%$ of biomass yield on optimum plantation density (1112 plants/ha). Total bamboo production was estimated based on proposed biomass yield and wasteland area considered for bamboo production. Bamboo biomass value chain analysis and commercial application potential was evaluated considering following products:

\section{Incense sticks production}

Harvested bamboo biomass was used by incense stick production unit. Based on processing steps efficiency and conversion ratio, overall production efficiency was calculated and on the basis of its' current market value, total economic revenue was estimated for proposed bamboo biomass production from marginal wasteland.

\section{Handicraft and construction industries}

Bamboo strips based handicraft products are widely used. Dry poles of bamboo are also used in construction industries. On the bases of bamboo market selling price for handicraft industry and construction industry, revenue generation estimations were done for bamboo annual production from marginal wasteland for both of these industries. Moreover, employment generations were also estimated for above bamboo bases commercial processes.

\section{Energy pellets and bioethanol production from incense stick waste}

Biofuel pellets were produced from bamboo biomass waste of incense sticks production unit and biofuel properties of the same were evaluated at lab. Similarly, bamboo biomass waste can also be used for fuel grade lignocellulosic bioethanol production through fermentation technology. Thus, economic projections from energy pellet production as well as bioethanol production along its' by-products were also made on the bases of conversion efficiency and market price of the final end products and by-products.

\section{Activated charcoal production}

Bamboo biomass was subjected to acid treatment followed by heating at $400{ }^{\circ} \mathrm{C}$ and $800{ }^{\circ} \mathrm{C}$ for production of activated carbon (Figure 1). On the basis of current market value of activated charcoal and bamboo production from marginal wasteland, annual economic revalue was estimated.

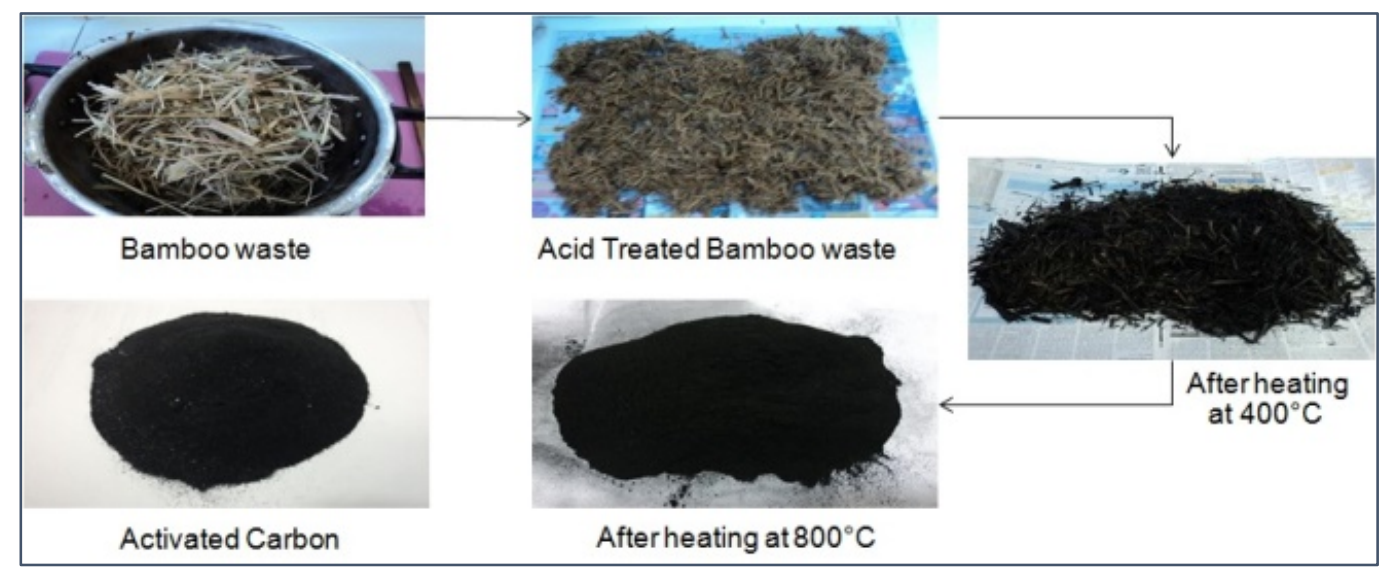

Figure 1. Activated Charcoal Production from bamboo biomass

Besides the economic value of application potential of bamboo in above mentioned commercial domains, $\mathrm{CO}_{2}$ sequestration \& wasteland reclamation along with reduction in imports \& GHG emissions were also estimated for bamboo production on marginal ecology of India.

\section{Assumptions and Secondary Data for Calculations}

Few common data/assumptions were considered to perform economic, environmental and social impact assessment of commercial scale bamboo production after validation through published data from public and private domains (Table 1). 
Table 1. Assumptions and secondary data used for value chain analysis of bamboo production

\begin{tabular}{|c|c|c|}
\hline Parameters & Value & Source \\
\hline Total Wasteland in India & 46.8 million Hectares & $\begin{array}{l}\text { Wasteland Atlas of India (Department of Land } \\
\text { Resources 2010) }\end{array}$ \\
\hline $\mathrm{CO}_{2}$ sequestration rate for bamboo & $1.2 \mathrm{Kg} \mathrm{CO}_{2}$ per $\mathrm{Kg}$ biomass & (Janssen 2000) \\
\hline $\mathrm{CO}_{2}$ emission from Coal & $2.42 \mathrm{Kg} \mathrm{CO}_{2}$ per $\mathrm{Kg}$ coal & \multirow{2}{*}{$\begin{array}{l}\text { IPCC guidelines 2006, volume 2, chapter 2, pg no } \\
2.16 \text { (Introgovernmental panel on climate change } \\
\text { (IPCC) 2006) }\end{array}$} \\
\hline $\mathrm{CO}_{2}$ emission from LPG & $1.5 \mathrm{Kg} \mathrm{CO}_{2}$ per liter & \\
\hline Coal replacement by energy pellets & 1.17 tonne coal/ton energy pellets & Based on energy content analysis at lab scale \\
\hline $\begin{array}{l}\text { Direct employment in bamboo biomass } \\
\text { production }\end{array}$ & $\begin{array}{l}\sim 2.5 \text { person per hectare }(1 \text { person per } \\
\text { acre) }\end{array}$ & $\begin{array}{l}\text { Assumption on the bases of data from incense } \\
\text { stick industry survey }\end{array}$ \\
\hline $\begin{array}{l}\text { Indirect employment in Incense sticks } \\
\text { production and other value chain }\end{array}$ & 1.5 times of direct employment & $\begin{array}{l}\text { Assumption on the bases of secondary data } \\
\text { analysis }\end{array}$ \\
\hline Market value of low grade lignin & $\sim 300 \mathrm{USD} / \mathrm{MT}$ & \multirow{2}{*}{$\begin{array}{l}\text { High-Value Opportunities for Lignin: Unlocking } \\
\text { its Potential (Smolarski 2012) }\end{array}$} \\
\hline Market value of high grade lignin & $\sim 2500 \mathrm{USD} / \mathrm{MT}$ & \\
\hline $\begin{array}{l}\text { Activated Charcoal production from } \\
\text { bamboo biomass }\end{array}$ & $\sim 0.3 \mathrm{MT}$ per MT bamboo biomass & (Kate 2014) \\
\hline Market rate of activated Charcoal & $1.7 \mathrm{USD} / \mathrm{kg}$ & $\begin{array}{l}\text { Average of current market rate from lower to } \\
\text { higher quality standards }\end{array}$ \\
\hline
\end{tabular}

\section{RESULTS AND DISCUSSIONS}

\section{Bamboo Agronomy Yield and Economy}

Figure 2 shows bamboo cultivation at captive farming sites, at farmers' field, harvesting of bamboo and sun drying of harvested bamboo culms.

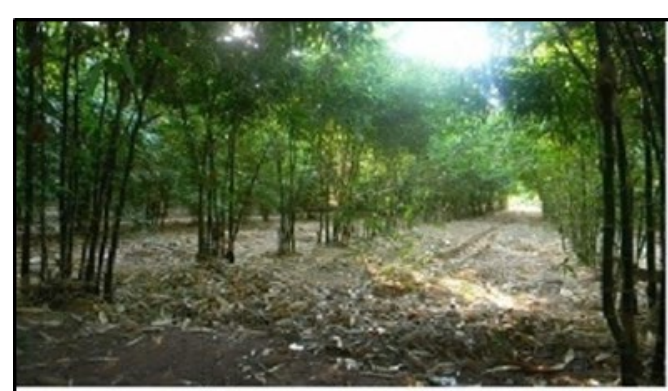

Captive farming site (1112 plants/ha)

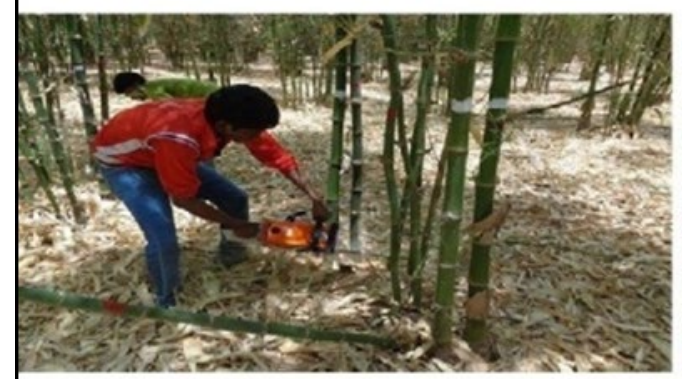

Bamboo Harvesting

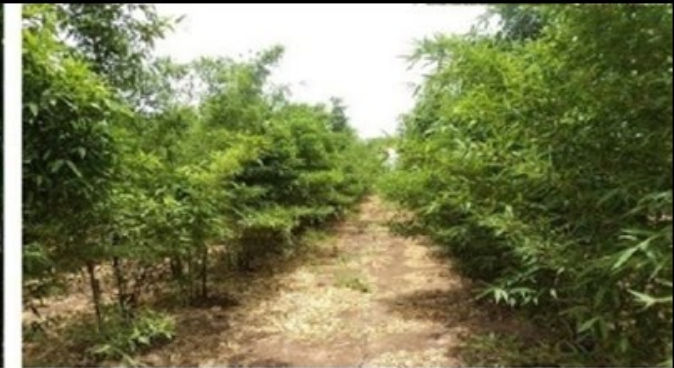

Farmers' Field (1112 plants/ha)

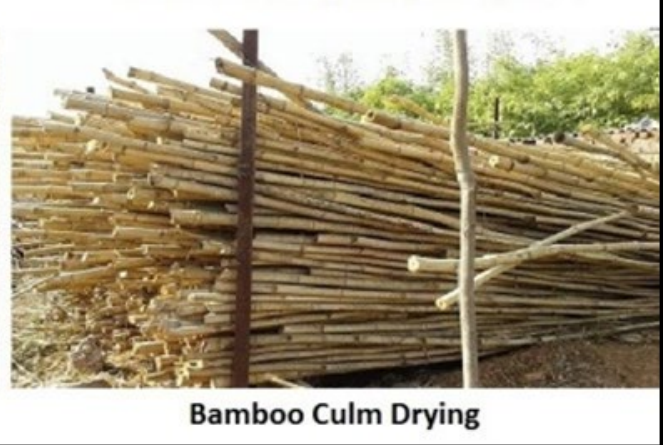

Figure 2. B. balcooa cultivation, harvesting and drying

Bamboo cultivation at captive farming was carried out using four densities of plantation that is 1112 plants/hectare, 2223 plants/hectare, 2964 plants/hectare and 6175 plants/hectare. It was observed that bamboo biomass yield in terms of dry culms (Matric tones/hectare) decreases as plantation density increases. Biomass yield was found to be highest of $57.7 \mathrm{Mt} / \mathrm{Ha}$ at 1112 plants/hectare density at captive farming as well as at farmers' field trials (43-54 Mt/Ha) as shown in Table 2. Piouceau et al. (2014) and Yourmila and Bhardwaj (2017) reported that higher competition for nutrients and water among the bamboo plants results into decrease in the survival rate of bamboo plants at higher densities (Piouceau et al., 2014; Yourmila and Bhardwaj, 2017). Increase in number of clumps in higher plantation density results into lack of growth space making competition for light, space and nutrients which reduces growth of new rhizome and culms (Kigomo and Kamiri, 1985) consequential less biomass productivity, confirms an inverse association as higher the plantation densities inferior the biomass yield (Kittur et al., 2016). 
European Journal of Sustainable Development Research, 3(4), em0103

Table 2. Cost calculation for Bambusa balcooa cultivation for three years at captive farm and farmer's field

\begin{tabular}{|c|c|c|c|c|c|c|c|}
\hline \multirow[b]{2}{*}{ Yield and cost parameters } & \multicolumn{4}{|c|}{ Captive farming } & \multicolumn{3}{|c|}{ Farmers' field trials } \\
\hline & $\begin{array}{c}\text { A1 (1112 } \\
\text { plants/ha) }\end{array}$ & $\begin{array}{c}\text { A2 (2223 } \\
\text { plants/ha) }\end{array}$ & $\begin{array}{c}\text { A3(2964 } \\
\text { plants/ha) }\end{array}$ & $\begin{array}{c}\text { A4(6175 } \\
\text { plants /ha) }\end{array}$ & $\begin{array}{c}\text { B1(1112 } \\
\text { plants/ha) }\end{array}$ & $\begin{array}{c}\text { B2(1112 } \\
\text { plants/ha) }\end{array}$ & $\begin{array}{c}\text { B3(1112 } \\
\text { plants/ha) }\end{array}$ \\
\hline $\begin{array}{l}\text { Land Preparation Cost } \\
\text { (USD/ha) }\end{array}$ & 22.58 & 22.58 & 22.58 & 22.58 & 11.29 & 11.29 & 11.29 \\
\hline Plant Cost (USD/ha) & 555.50 & 1110.99 & 1481.32 & 3086.09 & 555.50 & 555.50 & 555.50 \\
\hline Fertilizer Cost (USD/ha) & 196.12 & 392.23 & 0.00 & 0.00 & 196.12 & 196.12 & 196.12 \\
\hline Pruning Cost (USD/ha) & 150.54 & 176.89 & 195.70 & 0.00 & 150.54 & 150.54 & 150.54 \\
\hline Rotavator Cost (USD/ha) & 135.49 & 112.91 & 112.91 & 0.00 & 135.49 & 135.49 & 135.49 \\
\hline Weeding Labour (USD/ha) & 115.16 & 115.16 & 76.78 & 0.00 & 115.16 & 115.16 & 115.16 \\
\hline Electricity Bill (USD/ha) & 33.87 & 33.87 & 33.87 & 33.87 & 33.87 & 33.87 & 33.87 \\
\hline Organic Manure (USD/ha) & 83.66 & 167.33 & 223.10 & 0.00 & 83.66 & 83.66 & 83.66 \\
\hline $\begin{array}{l}\text { Total Cultivation Cost } \\
\text { (USD/ha), a }\end{array}$ & 1292.92 & 2131.96 & 2146.26 & 3142.54 & 1281.63 & 1281.63 & 1281.63 \\
\hline $\begin{array}{l}\text { Biomass Yield (culm) } \\
\text { (MT/ha), b }\end{array}$ & 57.70 & 40.76 & 38.24 & 28.41 & 51.62 & 54.44 & 43.13 \\
\hline Harvesting Cost (USD/MT), c & 9.37 & 9.37 & 9.37 & 9.37 & 9.37 & 9.37 & 9.37 \\
\hline $\begin{array}{l}\text { Harvesting Cost (USD } / \mathrm{ha}), \mathrm{d} \\
=\mathrm{b}^{*} \mathrm{c}\end{array}$ & 540.68 & 381.87 & 358.29 & 266.18 & 483.74 & 510.13 & 404.12 \\
\hline $\begin{array}{l}\text { Final bamboo production Cost } \\
\text { (USD/ha), } a+d\end{array}$ & 1833.60 & 2513.83 & 2504.56 & 3408.72 & 1765.37 & 1791.76 & 1685.75 \\
\hline $\begin{array}{l}\text { Per MT bamboo production } \\
\text { Cost (USD/MT) }\end{array}$ & 31.78 & 61.68 & 65.50 & 120.00 & 34.20 & 32.91 & 39.09 \\
\hline
\end{tabular}

Captive farming: A1=1112 plants/ha, A2=2223 plants/ha, A3=2964 plants/ha and A4=6175 plants/ha, Farmers' field trials: B1=Laxmipura, B2= Vadod and B3=Aakru

Soil and agro-climatic conditions were meagre in the present bamboo captive plantation and farmers' field trials. Plantation density of 1112 plants/hectare showed greater biomass yield with less density of plants. Patil et al. (1994) recommended for marginal land to have standing culm density of $15000-21000$ per hectare after $4^{\text {th }}$ year of plantation (Patil, Patil, and Hanamashetti 1994). In this study, 1112 plants/ha density showed culms/ha of $14760 \pm 1.79$ after $3^{\text {rd }}$ year of growth (culms data not shown).

Cost of cultivation of bamboo was calculated for each density for captive farming trials as well as for farmers' filed trial (Table 2). A1 plantation density (1112 plants/ha) showed highest bamboo dry biomass production of $57.70 \mathrm{MT} /$ ha resulting into cost of bamboo production and harvesting of around $31.78 \mathrm{USD} / \mathrm{MT}$ of dry biomass. This was almost similar for B1-B3 density plantation at farmers' field trial (34.20 USD/MT, 32.91 USD/MT, 39.09 USD/MT) respectively. Similar cost of production per metric tonne of biomass in south Indian region was reported by Biju Abraham (2017). Other densities at captive farming A2, A3 and A4 showed higher cost of production per metric tonne of biomass because of lower biomass yield (Table 2). INBAR testified 342.46 USD/ha/year as capital cost to get 4500 culms as output (JaingHua and XiaoSheng, 2001). Bamboo plantation cost of $192 \mathrm{USD} / \mathrm{ha} /$ year for 400plants/ha density was reported at Mahi ravine in India with output of 1500 poles/ha that accounted 0.13 USD/pole (Pande et al., 2012). Economics of bamboo plantation was carried out by various groups as per their study objective (Abraham, 2017; Growmore biotech Ltd., 2018; Pande et al., 2012). This study focused on marginal land cultivation of Bambusa balcooa plantation with various plantation densities and its validation on farmers' field for similar ecologies of agronomic conditions.

\section{Marginal Waste Land Cultivation Potential for Bamboo}

National biofuel policy promotes use of wasteland for cultivation of non-food biomass crops. Wasteland in India accounting for $46.8 \mathrm{M}$ ha (14.91\% of TGA) (Ministry of New \& Renewable Energy- Government of India Ministry, 2009; MRD, 2011).

Agronomic practices of Bambusa balcooa were established in this study at marginal ecologies in Gujarat state of India to understand economics and yield data of bamboo biomass production. Planting densities are an important aspect which requires optimization for enhancing productivity of biomass through canopy development, retention of soil moisture and competition with weeds (JaingHua and XiaoSheng, 2001). Therefore, this study was carried out to know optimum planting density of Bambusa balcooa at marginal land type as captive farming and farmers' field with different densities to determine best productivity as against cultivation cost.

Bamboo cultivation and its yield at marginal wastelands and its economic projections were estimated and described in Table 3 . Only $5 \%$ of marginal wasteland was considered for cultivation of bamboo and the bamboo yield on marginal land was also estimated at $50 \%$ of its actual yield due to marginal ecology of wasteland. 
Table 3. Potential of B. balcooa cultivation at marginal wastelands and its economic value

\begin{tabular}{ll}
\hline Parameters & Value \\
\hline Total Wasteland in India & 46.8 million hectares \\
\hline Bamboo cultivation on $5 \%$ of total wasteland & 2.335 million hectares \\
\hline Bamboo Yield (50\% of 57.7 MT/ha at 1112plants/ha density) & 28.85 tonne/ha/year \\
\hline Total bamboo production from wasteland $(2.33$ million hectares) & $67.51 \mathrm{mMT} /$ year \\
\hline
\end{tabular}

Cultivation of B. balcooa on 5\% of marginal waste land i.e. 2.335 million hectares would provide employment to 5.77 million people with yield of 67.51 million metric tonne of B. balcooa biomass per year.

It has been reported that every 2, 50000 ha of plantation annually can create 40 million man-days of rural employment over five years (Tardio et al., 2016).

Taxonomically bamboo is a grass with properties of fast growth and rejuvenation after cutting. It flourishes in diverse climatic and soil conditions (Gami, Syed, and Patel 2015) which makes bamboo a consistent source of biomass for bioenergy (Scurlock, Dayton, and Hames 2000).

\section{Bamboo in Small Scale Industries}

\section{Use of Bamboo biomass in handicraft and construction industry}

Dry poles and strips of bamboo culms are used in construction industries and handicraft industries respectively (Figure 3). While considering 114 USD/tonne of market price, total revenue of 7696.14 million USD can be generated through construction industry from bamboo produced on marginal land of India. Similarly, total revenue of 9788.95 million USD per year can be generated through handicraft industry considering market price of 145 USD/tonne. Moreover, direct employment (around 2.5 persons/ha) of 5.77 million people can also be generated from bamboo cultivation on marginal land. Bamboo would support Make in India and Skill India initiative of Government of India through employment to the local youth in handicraft industries. It would provide employment to women of the rural regions as handicraft industry fosters women to learn and apply their skills. Employment to women in handicraft industries would empower them and provide financial independence and upliftment of women and strengthen their role in decision making in households.

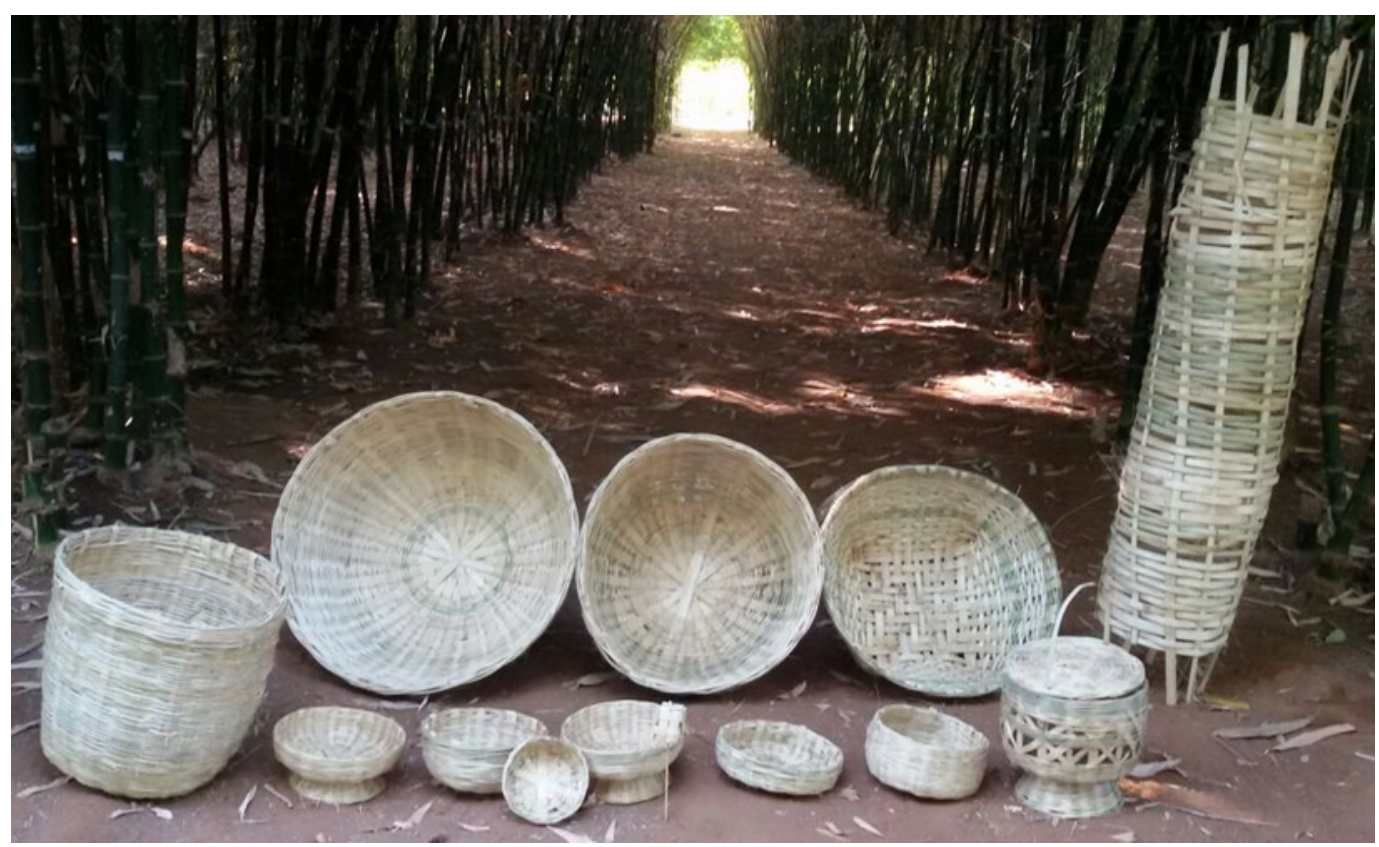

Figure 3. Bamboo based handicraft products

\section{Cottage industrial application of Bamboo}

Bamboo biomass is widely used in incense sticks/toothpick/chopsticks production. However, incense sticks production process is very inefficient and generates $\sim 80 \%$ waste biomass (Figure 4). From total $67.51 \mathrm{mMT}$ bamboo productions from marginal land of India, $12.83 \mathrm{mMT}$ incense sticks can be produced with $19 \%$ production efficiency. Overall process with efficiency at each step of production has been described in Figure 4. While considering 1295.14USD/tonne of sell price for incense stick/toothpick/chopsticks, total revenue of 16617 million USD can be generated a year. 


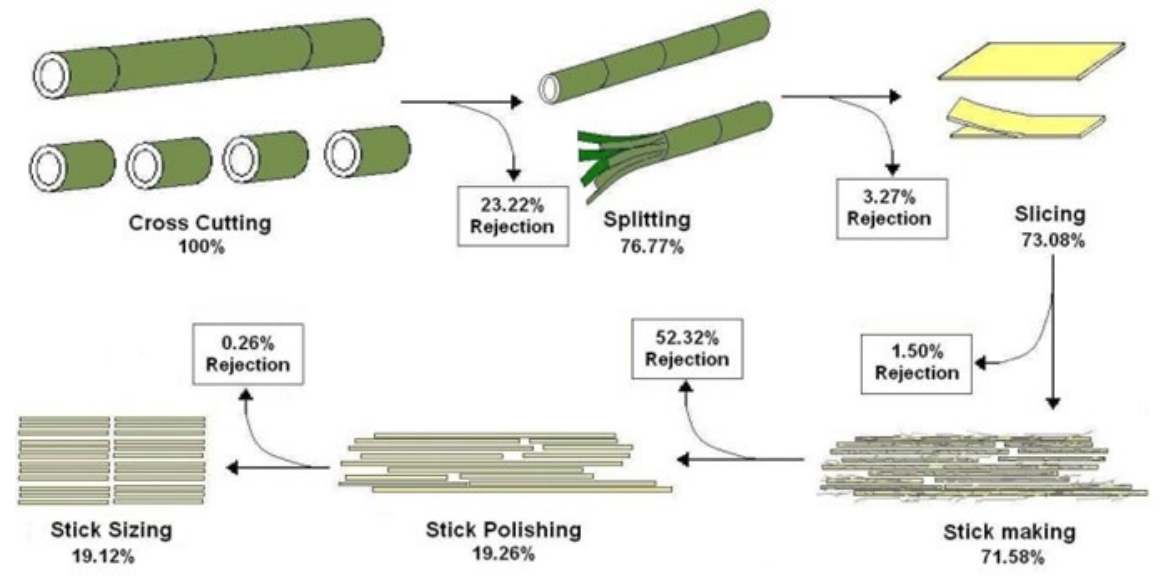

Figure 4. Incense sticks production from bamboo

The annual production of bamboo in India is about $14.6 \mathrm{mMT}$ and annual productivity varies from 1 to $3 \mathrm{MT}$ ha $^{-1}$ (National Bamboo Mission, 2019). India is a net importer of bamboo which implies that there are greater opportunities to harness the market potential by increasing its production (INBAR, 2012). It has been reported that around 600 workdays are required per tonne of bamboo in the primary processing. The average consumption of bamboos in the incense stick industry is 15000 tonnes per annum (Tardio et al., 2016).

Besides incense sticks industries, bamboo biomass is used energy pellets production (Truong and Anh Le, 2014), fuel grade bioethanol \& lignin based other value added products and electricity generation (INBAR, 2016) and activated charcoal production (Hakeem et al., 2015).

\section{Energy and Bio-refinery Application of Bamboo Biomass Waste}

\section{Energy Pellet production}

Waste biomass generated from incense sticks can be used in energy pellets production (Figure 5). While considering $80 \%$ waste from total bamboo biomass in incense sticks production process, total $54.00 \mathrm{mMT}$ energy pellets can be produced per annum from bamboo cultivated on marginal land. Thus, energy pellets produced from incense sticks waste itself can generate revenue of 13,987 million USD per annum with energy pellet market rate of $259.02 \mathrm{USD} /$ tonne.

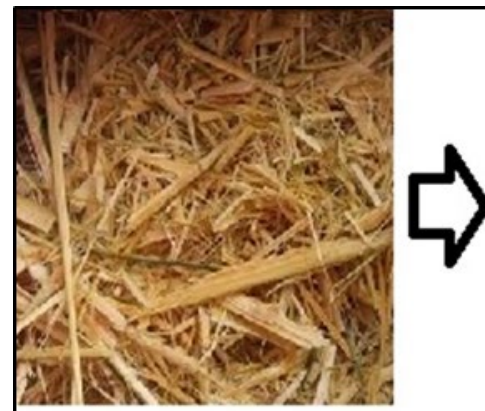

Bamboo waste

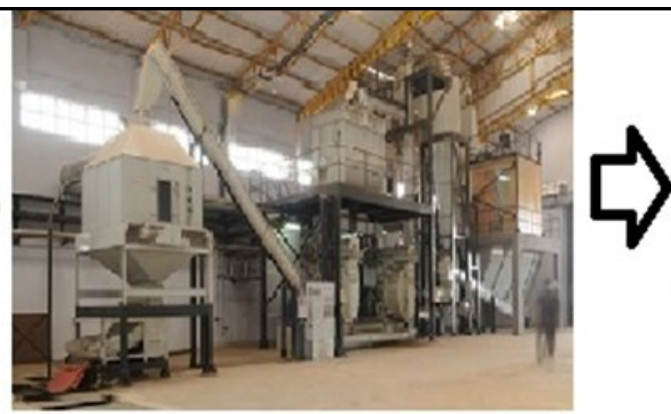

Pellet Mill

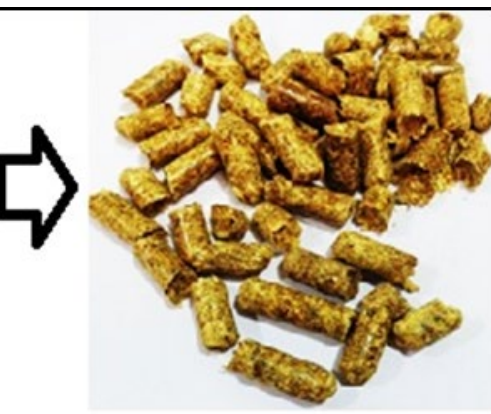

Energy Pellets

Figure 5. Energy pellets production from bamboo

If we consider the environmental benefits of the energy pellet production form bamboo, total $63.18 \mathrm{mMT}$ coal can be replaced per year considering 1.17 tonne coal/tonne energy pellets based on energy value of both fuels. Now, if we consider $\mathrm{CO}_{2}$ emission reduction against coal at 1.78 tonne $\mathrm{CO}_{2} /$ tonne pellets, total $96.12 \mathrm{mMT} \mathrm{CO}_{2}$ emissions can be reduced per year. Similarly, total $21.60 \mathrm{mMT}$ LPG can be replaced per year considering 0.4 tonne LPG/tonne energy pellets and as per $\mathrm{CO}_{2}$ emission reduction against LPG at $1.51 \mathrm{~kg} \mathrm{CO} / \mathrm{L} \mathrm{LPG}$, total 63.93 $\mathrm{mMT} \mathrm{CO} 2$ emissions can be reduced annually. Moreover, energy pellet production from bamboo waste of incense sticks production can also generate additional indirect employment of around 8.66 million people considering 1.5 times of direct employment. Bamboo is globally considered as potential source of bioenergy due to its required fuel characteristics having calorific value of $\sim 4000 \mathrm{kcal} / \mathrm{kg}$ which can be used for bio-pellets production that can replace alternative fuel like coal, lignite and furnace oil in boiler (FAO, 2016; Gami et al., 2015; B. Patel et al., 2017). 
B. balcooa waste generated from incense sticks in energy pellets production would reduce 63.18 million tonnes/year consumption of coal with 96.12 million tonne/year $\mathrm{CO}_{2}$ reduction. This initiative supports India's INDC declared at COP-21 for reduction in the emissions intensity by 33-35\% of its GDP by 2030 from 2005 level (Government of India, 2016). Besides environmental impacts, utilization of B. balcooa waste would also provide employment to around 8.66 million people in production, transportation and marketing of the energy pellets.

\section{Fuel grade bioethanol and lignin-based products}

Bamboo biomass is also one of the efficient biofuel feed stocks for fuel grade bioethanol production. Size reduced and shredded bamboo biomass used as feedstock and bioethanol produced through fermentation technology. Alternatively, B. balcooa waste from incense sticks industries can also be used in production of fuel grade bioethanol production yielding 7560 million liter bioethanol/year valued at 5670 million USD (Table 4). It would support achieving 20\% blending mandate of bioethanol by Biofuel Policy of India (MNRE) in 2009. Lignin based low- and high-grade refinery products can further attract 3240USD/year and 1340 USD/year respectively.

Table 4. Revenue estimation for fuel grade bioethanol production from incense sticks waste

\begin{tabular}{ll}
\hline Parameter & Value \\
\hline Total bamboo production from marginal wasteland $(2.33$ million hectares) & $67.51 \mathrm{mMT} /$ year \\
\hline Fuel grade bioethanol production from 80\% waste @ $140 \mathrm{~L} /$ tonne of bamboo & 7560 million litre Bio-ethanol/year \\
\hline Total value realization from bioethanol @0.75USD/L & 5670 million USD/year \\
\hline Total lignin during bioethanol production from 80 \% waste @ $0200 \mathrm{~kg} /$ tonne & $10.80 \mathrm{mMT}$ lignin/year \\
\hline Total value if low grade lignin based products are developed @,300 USD/tonne & 3240 million USD/year \\
\hline Total value from high grade products (vanillin, phenol, BTX etc.) at $5 \%$ of lignin & 1350 million USD/year \\
\hline
\end{tabular}

\section{Activated charcoal production}

Bamboo biomass can also be used for production of high value commodity like activated charcoal. Charcoal absorbs odour and toxic pollutants from water or air by trapping through the pores present on its surface. Activated bamboo charcoal is comparatively more porous than normal charcoal hence shows higher effectiveness among charcoals from other materials. Bamboo biomass was subjected to acid treatment followed by heating at $400{ }^{\circ} \mathrm{C}$ and $800{ }^{\circ} \mathrm{C}$ for production of activated carbon (Figure 1). As mentioned in Table 3, if $67.51 \mathrm{mMT}$ bamboo biomass can be produced per year on marginal waste land, total $20.25 \mathrm{mMT}$ activated charcoal can be produced per annum considering 30\% final conversion efficiency. Total revenue of 34425 million USD can be estimated considering average market price of $1700 \mathrm{USD} /$ tonne of activated charcoal.

\section{Environmental Impact}

\section{Soil improvement}

Cultivation of bamboo improves soil quality as evident by decreased $\mathrm{pH}$ and increased TDS, conductivity, nitrogen content, organic matter and organic carbon of the soil at all sites while potassium, phosphorus, calcium content and C:N ratio varied at different sites (Table 5).

Table 5. Soil analysis of Bambusa balcooa cultivation at captive farm of Abellon and farmers' field trials

\begin{tabular}{|c|c|c|c|c|c|c|c|c|c|c|c|c|c|c|}
\hline \multirow[b]{2}{*}{$\begin{array}{l}\text { Months after } \\
\text { Planting }\end{array}$} & \multicolumn{2}{|c|}{$\begin{array}{c}\text { A1 (1112 } \\
\text { plants/ha) }\end{array}$} & \multicolumn{2}{|c|}{$\begin{array}{c}\text { A2 (2223 } \\
\text { plants/ha) }\end{array}$} & \multicolumn{2}{|c|}{$\begin{array}{c}\text { A3(2964 } \\
\text { plants/ha) }\end{array}$} & \multicolumn{2}{|c|}{$\begin{array}{c}\text { A4(6175 } \\
\text { plants/ha) }\end{array}$} & \multicolumn{2}{|c|}{$\begin{array}{c}\text { B1(1112 } \\
\text { plants/ha) }\end{array}$} & \multicolumn{2}{|c|}{$\begin{array}{c}\text { B2(1112 } \\
\text { plants/ha) }\end{array}$} & \multicolumn{2}{|c|}{$\begin{array}{c}\text { B3(1112 } \\
\text { plants/ha) }\end{array}$} \\
\hline & Initial & $\begin{array}{c}\text { After } 3 \\
\text { years }\end{array}$ & Initial & $\begin{array}{c}\text { After } 3 \\
\text { years }\end{array}$ & Initial & $\begin{array}{c}\text { After } 3 \\
\text { years }\end{array}$ & Initial & $\begin{array}{c}\text { After } 3 \\
\text { years }\end{array}$ & Initial & $\begin{array}{c}\text { After } 3 \\
\text { years }\end{array}$ & Initial & $\begin{array}{c}\text { After } 3 \\
\text { years }\end{array}$ & Initial & $\begin{array}{c}\text { After } 3 \\
\text { years }\end{array}$ \\
\hline $\mathrm{pH}$ & 7.16 & 7.09 & 7.57 & 7.12 & 7.52 & 7.22 & 7.60 & 6.96 & 8.06 & 7.53 & 8.01 & 7.48 & 8.26 & 7.78 \\
\hline TDS, ppm & 50.0 & 65.0 & 84.0 & 88.0 & 64.0 & 71.0 & 120 & 132 & 500 & 535 & 495 & 531 & 526 & 561 \\
\hline $\begin{array}{l}\text { Conductivity, } \\
\mathrm{ms} / \mathrm{cm}\end{array}$ & 0.08 & 0.10 & 0.13 & 0.14 & 0.10 & 0.11 & 0.19 & 0.21 & 0.78 & 0.84 & 0.77 & 0.83 & 0.82 & 0.88 \\
\hline Nitrogen, $\%$ & 0.08 & 0.12 & 0.07 & 0.13 & 0.11 & 0.14 & 0.13 & 0.14 & 0.04 & 0.21 & 0.04 & 0.12 & 0.03 & 0.15 \\
\hline Phosphorus, \% & 0.21 & 0.22 & 0.29 & 0.28 & 0.36 & 0.26 & 0.18 & 0.12 & 0.04 & 0.17 & 0.03 & 0.21 & 0.04 & 0.22 \\
\hline Potassium, $\%$ & 0.06 & 0.09 & 0.08 & 0.08 & 0.12 & 0.09 & 0.07 & 0.06 & 1.47 & 1.78 & 1.25 & 1.48 & 1.62 & 1.89 \\
\hline Calcium, \% & 0.49 & 0.40 & 0.52 & 0.45 & 0.42 & 0.31 & 0.47 & 0.27 & 0.37 & 0.62 & 0.31 & 0.63 & 0.34 & 0.70 \\
\hline Organic Matter, $\%$ & 0.55 & 1.29 & 0.63 & 1.44 & 0.55 & 0.87 & 0.46 & 0.84 & 0.36 & 2.51 & 0.34 & 1.51 & 0.29 & 1.68 \\
\hline Organic Carbon, $\%$ & 0.32 & 0.75 & 0.37 & 0.84 & 0.32 & 0.51 & 0.27 & 0.49 & 0.21 & 1.46 & 0.2 & 0.88 & 0.17 & 0.98 \\
\hline C:N ratio & 4.0 & 6.25 & 5.29 & 6.46 & 2.91 & 3.64 & 2.08 & 3.50 & 5.25 & 6.95 & 5.00 & 7.33 & 5.67 & 6.53 \\
\hline
\end{tabular}


Bamboo's ability for providing environmental services through carbon sequestration is receiving high levels of interest which also confirms that bamboo outstrips its rate of carbon accumulation as against some fast growing trees (Lou et al., 2010). Further Bamboo thrives on nutrient poor soils with less silvicultural requirement yielding higher biomass besides having versatile diverse uses, surface root structure that improves soil ecosystem, absorb more $\mathrm{CO}_{2}$ and produce more oxygen, nutrient cycling in improving soil fertility due to its vigorous growth and litter production (Yourmila and Bhardwaj, 2017).

\section{Carbon Dioxide fixation}

Climate change is one of negative impacts of increased carbon dioxide concentration in an atmosphere. The rise of carbon dioxide concentration resulted from uncontrolled use of fossil fuels. There are many heat trapping gases like methane, $\mathrm{NOx}$, SOx etc. but among these all, $\mathrm{CO}_{2}$ can generate greater risk if continuously accumulate in atmosphere. There are many $\mathrm{CO}_{2}$ sequestration techniques on which researchers are working; however biological sequestration through biomass production is more sustainable among all.

Total GHG reductions through feedstock production on this marginal land were also calculated on the basis of total amount of $\mathrm{CO}_{2}$ eq. sequestered by production of one metric ton of dry bamboo biomass. Considering 1.2 $\mathrm{tCO}_{2}$ sequestrated per metric ton of dry bamboo biomass, bamboo cultivation on 46.8 million hectares of marginal land can fix total 81.01 million $\mathrm{tCO}_{2}$ per year.

B. balcooa is a promising biomass source, owing to its fast growth, rapid regeneration, high $\mathrm{CO}_{2}$ sequestration and wasteland reclamation potential. India is the second richest country in terms of bamboo genetic resources (Forest Survey of India, 2011). Bamboo forests cover 13.96 million hectares (Mha) ( 13\% of total forest cover) in India (MoEF, 2012). It can be used as "carbon sink" as it has very high $\mathrm{CO}_{2}$ sequestration potential than most forest trees (Yiping et al., 2010).

\section{CONCLUSION}

The use of bamboo in any industry may not be economically viable option due to inefficient production processes, high logistics cost, high amounts of waste generation, poorly managed supply chain etc. Thus, an integrated model involving various industries needs to be designed for efficient utilization of bamboo biomass with cost effective production system with local support to reduce logistics cost and marketing costs. Thus, cultivation of bamboo on marginal wasteland for various industrial applications is a cost effective, environment friendly option.

Bamboo has higher sequestration potential than most forest trees so Government should promote its cultivation through incentive mechanism. Policies should be framed wherein bamboo cultivation for the industries emitting high amounts of GHGs and $\mathrm{CO}_{2}$ to mitigate the effects of emission and help to achieve the India's Intended Nationally Determined Contribution (INDC) submitted during $21^{\text {st }}$ Conference of Parties (COP21).

Cultivation of bamboo on marginal land would provide employment to local youth in bamboo based industries and impart skills to the youth supporting "Skills India" launched by Govt. of India in July 2015. Products from bamboo industries would contribute to "Make in India" initiative launched by Govt. of India in September 2014. Ministry of Road Transport \& Highways and Shipping, proposed cultivation of bamboo on the sides of state \& national highways as an energy crop and biomass source for bioethanol production along with $\mathrm{CO}_{2}$ sequestration $\&$ creation of job opportunities to around 50 lakh people. Local farmers should also be encouraged and provided incentives for cultivation of boundaries of their farms to retain soil moisture, protect crops from extreme climatic conditions and prevent hot summer winds from damaging the crop.

\section{ACKNOWLEDGEMENT}

Authors are thankful to The Indo-US Science and Technology Forum (IUSSTF) and Department of Biotechnology (DBT), Government of India, New Delhi, for financial support in farmers' field trials conducted in this study by providing grant under US-India Sustainable Advanced Lignocellulosic Biofuel Systems (SALBS) project. Authors are thankful to Abellon Agrisciences Ltd. for conducting agronomical trials for this study. 


\section{REFERENCES}

Abraham, B. (2017). The New Green Gold of the Poor Farmer's Bamboo Cultivation for a Sustained Livelihood. Shanlax International Journal of Economics, 5(4), 24-33.

Bhuvaneshwari, S., Hettiarachchi, H. and Meegoda, J. N. (2019). Crop Residue Burning in India: Policy Challenges and Potential Solutions. International Journal of Environmental Research and Public Health, 16(5), 19. https://doi.org/10.3390/ijerph16050832

BTSG-KFRI. (2015). Manual for Establishment and Management of Bamboo Plantations. Kerala.

Department of Land Resources. (2010). Wasteland Atlas of India.

FAO. (2016). Forestry for a Low-Carbon Future. Vol. 177. Rom: Food and Agriculture Organization of the United Nations, Rome.

Forest Survey of India. (2011). Bamboo Resources of the Country-India' in 'State of Forest Report 2011. Ministry of Environment \& Forests. Available at: http:/ / fsi.nic.in/cover_2011/chapter6.pdf (Accessed 12 September 2019)

Gami, B. and Syed, B. A. (2015). Assessment of Genetic Diversity in Bamboo Accessions of India Using Molecular Markers. Int J Appl Sci Biotechnol, 3(2), 330-336. https://doi.org/10.3126/ijasbt.v3i2.12587

Government of India. (2016). India's Intended Nationally Determined Contirbution: 1-38. Available at: http://www4.unfccc.int/ndcregistry/PublishedDocuments/India First/INDIA INDC TO UNFCCC.pdf (Accessed 18 September 2019)

Growmore biotech Ltd. (2018). Bamboo Economics. Available at: http://growmorebiotech.com/bamboo_economics.htm (Accessed 4 September 2018)

Gu, L., Zhou, Y., Mei, T., Zhou, G. and Xu, L. (2019). Carbon Footprint Analysis of Bamboo Scrimber FlooringImplications for Carbon Sequestration of Bamboo Forests and Its Products. Forests, 10(1), 1-14. https://doi.org/10.3390/f10010051

Hakeem, K. R., Ibrahim, S., Ibrahim, F. H. and Tombuloglu, H. (2015). Bamboo Biomass: Various Studies and Potential Applications for Value-Added Products. In K. R. Hakeem, M. Jawaid and O. Y. Alothman (Ed.) Agricultural Biomass Based Potential Materials (pp. 231-243). Cham: Springer International Publishing. https://doi.org/10.1007/978-3-319-13847-3_11

INBAR. (2012). International Trade of Bamboo and Rattan 2012. Beijing.

INBAR. (2016). Bamboo \& Rattan for Inclusive and Green Development- International Network for Bamboo \& Rattan. INBAR and ENEA Release the First Official Study Veriffing the Use of Bamboo Biomass for Energy Production 2.

Introgovernmental panel on climate change (IPCC). 2006. 2006 IPCC Guidelines for National Greenhouse Gas Inventories, Volume 2, Chapter 2.

Janssen, J. J. A. (2000). Designing and Building with Bamboo.

Kate, L. (2014). Could Bamboo Be the Bioenergy of the Future? World Agroforestry. Available at: http://blog.worldagroforestry.org/index.php/2014/10/10/could-bamboo-be-the-bioenergy-of-the-future/ (Accessed 5 September 2019)

Kigomo, B. N. and J. F. Kamiri. 1985. "Observation on the Growth and Yield of Oxytenanthera Abyssinica (A.Rich) Munro in Plantation.” East Afr. Agric. For. J. 51:22-29. https://doi.org/10.1080/00128325.1985. 11663456

Kittur, B. H., Sudhakara, K., Mohan Kumar, B., Kunhamu, T. K. and Sureshkumar, P. (2016). Bamboo Based Agroforestry System in Kerala, India: Performance of Turmeric (Curcuma Longa L.) in the Subcanopy of Differentially Spaced Seven Year Old Bamboo Stand. Agroforestry Systems, 90, 237-250. https://doi.org/10.1007/s10457-015-9849-z

Lou, Y., Li, Y., Kathleen, B., Giles, H. and Zhou, G. (2010). Bamboo and Climate Change Mitigation. Beijing, China.

Ministry of Agriculture. (2014). National Policy for Management of Crop Residues (NPMCR). Available at: http://agricoop.nic.in/sites/default/files/NPMCR_1.pdf (Accessed 5 September 2019)

Ministry of New \& Renewable Energy- Government of India Ministry. (2009). National Policy on Biofuels: 1-18.

MoEF. (2012). Report of Forest Survey of India in Forest Cover. Press Information Bureau, Ministry of Environment Forest and Climate Change. Available at: https://pib.gov.in/newsite/PrintRelease.aspx?relid=86980 (Accessed 13 September 2019)

MRD, Govt of India. (2011). Wastelands Atlas of India Wastelands Atlas of India.

NABARD. (2018). Sectoral Paper on Forestry. Mumbai.

National Bamboo Mission. (2019). Operational Guidelines of National Bamboo Mission. 39.

Pande, V. C., Kurothe, R. S., Rao, B. K., Kumar, G. K., Parandiyal, A. K., Singh, A. K. and Kumar, A. (2012). Economic Analysis of Bamboo Plantation in Three Major Ravine Systems of India. Agricultural Economics Research Review, 25(1), 49-59.

Patel, A., Gami, B., Patel, P. and Patel, B. (2017). Microalgae: Antiquity to Era of Integrated Technology. Renewable and Sustainable Energy Reviews, 71, 535-547. https://doi.org/10.1016/j.rser.2016.12.081 
Patel, B., Gami, B. and Patel, P. (2017). Carbon Sequestration by Bamboo Farming on Marginal Land and Sustainable Use of Wood Waste for Bioenergy: Case Studies from Abellon Clean Energy. In K. Krishna, V. Pandey, S. S. Ramakantha, A. N. Chauhan and A. Kumar (Ed.) Wood is Good Current Trends and Future Prospects in Wood Utilization (pp. 451-467). Singapore: Springer Nature Singapore Pte Ltd. https:/ / doi.org/10.1007/978981-10-3115-1_43

Patil, V. C., Patil, S. V. and Hanamashetti, S. I. (1994). Bamboo Farming: An Economic Alternative on Marginal Lands. In Proceedings of the 4th International Bamboo Workshop on Bamboo in Asia and the Pacific, Chiangmai, Thailand, 27-30 November 1991 (pp. 133-135). Forest Research Support Programme for Asia and the Pacific, Bangkok, Thailand.

Piouceau, J., Bois, G., Panfili, F., Anastase, M., Dufossé, L. and Arfi, V. (2014). Effects of High Nutrient Supply on the Growth of Seven Bamboo Species. International Journal of Phytoremediation, 16(10), 1042-1057. https://doi.org/10.1080/15226514.2013.810583

Scurlock, J. M. O., Dayton, D. C. and Hames, B. (2000). Bamboo: An Overlooked Biomass Resource. Biomass Bioenergy, 19, 229-244. https://doi.org/10.1016/S0961-9534(00)00038-6

Smolarski, N. (2012). High-V alue Opportunities for Lignin: Unlocking Its Potential Lignin Potential.

Tardio, G., Mickovski, S. B., Rauch, H. P., Fernandes, J. P. and Acharya, M. S. (2016). The Use of Bamboo for Erosion Control and Slope Stabilization: Soil Bioengineering Works. In Bamboo - Current and Future Prospects. (Vol. 7, pp. 13). https:// doi.org/10.5772/intechopen. 75626

Truong, A. H. and Le, T. M. A. (2014). Overview of Bamboo Biomass for Energy Production. University of Science and Technology of Hanoi.

World Energy Council. (2014). World Energy Resources: 2013 Survey. 45.

Xiao, J. H. and Yang, X. S. (2001). Medium and Large Scale Bamboo Plantations. International Network for Bamboo and Rattan (INBAR). Bamboo Research Division Research Institute of Subtropical Forestry, Zhejiang Province, China.

Yiping, L., Yanxia, L., Buckingham, K., Henley, G. and Guomo, Z. (2010). Bamboo and Climate Change Mitigation: A Comparative Analysis of Carbon Sequestration. Beijing.

Yourmila, K. and Bhardwaj, D. R. (2017). Effect of Various Bamboo Species on Soil Nutrients and Growth Parameters in Mid Hills of HP, India. International Journal of Chemical Studies, 5(4), 19-24. 